BIOMEDICAL AND BIOSOCIAL ANTHROPOLOGY
$\begin{gathered}\text { Official Journal of the International Academy } \\ \text { of Integrative Anthropology } \\ \text { journal homepage: http://bba-journal.com }\end{gathered}$

\title{
Determination of individual teleroentgenographic characteristics of the face profile in ukrainian young men and girls with orthognathic bite
}

Dmitriev M. 0 .

National Pirogov Memorial Medical University, Vinnytsya, Ukraine

\section{ARTICLE INFO}

Received: 5 July, 2018

Accepted: 21 August, 2018

UDC: $616.716 .8-071-084: 613.956$ :

617.52: $616.34 .25-007.481-7$

CORRESPONDING AUTHOR

e-mail: dmitriyevnik@gmail.com Dmitriev M. O.

\begin{abstract}
Modern dentistry requires the definition of individualized values of teleroentgenographic indicators. To solve such problems, methods of regression and correlation analysis are increasingly used, which help to establish not only the existence of various relationships between the anatomical structures of the head and the parameters of the dento-jaw system, but also allow more accurately predict the change in the contour of soft facial tissue in response to orthodontic treatment. The purpose of the study is to develop mathematical models for the determination of individual teleroentgenographic characteristics of the facial soft tissues by studying the cephalometric indices of young men and women of Ukraine with normal occlusion and balanced faces and conducting a direct stepwise regression analysis. With the use of Veraviewepocs $3 D$ device, Morita (Japan) from 38 young men (17 to 21 years of age) and 55 young women (aged from 16 to 20 years) with occlusal close to the orthognathic bite and balanced faces received side teleroentgenograms. The cephalometric analysis was performed using OnyxCeph? ${ }^{\mathrm{T} M}$ licensed software. Cephalometric points and measurements were made according to the recommendations of Downs W. B., Holdway R. A., McNamara J., Schwarz A. M., Schmuth G. P. F., Steiner C. C. and Tweed C. H. With the help of direct stepwise regression analysis, in the licensed package "Statistica 6.0", regression models of individual teleroentgenographic characteristics of the profile of soft facial tissues were constructed. In young men with normal occlusion close to the orthognathic bite of 19 possible models, 11 were constructed with a determination coefficient from 0.638 to 0.930 , and in young women - 12 models with a determination coefficient from 0.541 to 0.927 . The conducted analysis of models showed that in young men most often the regression equations included - angle N_POG, parameters of which indicate a linear interjaw relation in the anterior-posterior direction (14.0\%); angle GL_SNPOG, or index of convexity of the soft tissue profile (8.8\%); MAX maxillary length (7.0\%), and GL_SN_S index, which defines vertical correlations in the facial profile (5.3\%). The young women most often models included - the angle N_POG (12.5\%); angle GL_SNPOG (7.5\%); soft tissue front angle P_OR N (6.25\%); the reference angle $M L \_N L$ and the profile angle $T$ (by 5.0\%); the angle $\overline{A B} \_N P O G$, the angle NBA_PTGN, which defines the direction of development of the mandible and the distance $P N \_A$ (3.75\%). Thus, in the work with the help of the method of stepwise regression with inclusion, among Ukrainians of adolescence age, based on the characteristics of teleroentgenographic indicators, reliable models of individual teleroentgenographic characteristics of the profile of soft facial tissues were developed and analyzed. Keywords: soft tissue profile, cephalometric analysis, regression.
\end{abstract}

\section{Introduction}

Obtaining a proportional and balanced face, along with the right bite, is one of the desired results after treatment of orthodontic pathology. After changing the position and inclination of the anterior group of teeth, affecting the shape and size of the teeth, modifying the growth of the maxillary bones, the physician can change the ratio of soft tissues, thereby changing the facial expression and smile. A proportional harmonic face, its aesthetic perception, a 
beautiful smile of a person play a very important role in society, since, as a rule, they are associated with success, prosperity and well-being [3, 26]. Since treatment lasts for a long time and often there is no opportunity to go back, diagnosis and planning occupy leading positions in the activities of the doctor. And therefore, orthodontists, plastic and maxillofacial surgeons must have a clear mathematical understanding of such objective characteristics as attractiveness, harmony of aesthetics, beauty, whose subjective perception has been closely associated with cephalometric indices [19]. Lips, chin and nose are the main components of the face profile. Attempts to determine the objective patterns between angular and linear parameters of these components are most widely represented in different author methods of analysis of lateral teleroentgenograms. They allow simultaneously studying the bone and soft tissue structures that form the face profile [20, 21, 25]. The paradigm of modern teleroentgenographic diagnostics is being shifted to the point of considering just the aesthetic criteria, and not just the dental ones. After all, the profile of the face depends not only on the bone fundament [18], but also on the thickness of soft tissues, muscle tone, the presence of subcutaneous adipose tissue, and others [2, 4, 17, 27, 29].

But do there exist unified standards and standards for the planning of profile metric characteristics? With the development of science, more and more researches has been accumulated that proves the existence of statistically significant ethnic, sex [11, 24], age and constitutional differences in facial characteristics [1, 6, 8, 13-15, 30].

Data on the possibilities of identifying individual characteristics, the profile of soft tissues in Ukrainian young men and women in the literature not found.

The purpose of the study is to develop mathematical models for the determination of individual teleroentgenographic characteristics of the facial soft tissues by studying the cephalometric indices of young men and women from Ukraine with normal occlusion and balanced faces and conducting a direct stepwise regression analysis.

\section{Materials and methods}

With the use of Veraviewepocs 3D device, Morita (Japan) in 38 young men ( 17 to 21 years of age) and 55 young women (aged from 16 to 20 years) with occlusal close to the orthognathic bite and balanced faces received side teleroentgenograms. Cephalometric analysis was performed using OnyxCeph? ${ }^{\mathrm{TM}}$ licensed software. The analysis of teleroentgenograms and the results of their research for Ukrainian young women and men, as well as cephalometric points and measurements conducted in accordance with the recommendations of Schwarz A. M., McNamara J., Downs W. B., Holdway R. A., Schmuth P. F., Steiner C. C. and Tweed C. H. are described in detail and set out in a number of articles [7-10, 15, 16].

The publication is a fragment of the planned research work of the National Pirogov Memorial Medical University, Vinnytsya on the theme: "Clinical and experimental justification of the application of new methods of prevention, diagnosis, treatment of children and adolescents with anomalies of the dento-jaw system and complications of caries" (state registration number: 0115U007010).

The statistical processing of the obtained results was carried out in the license package "Statistica 6.0" using a direct stepwise regression analysis. In a direct stepwise regression analysis, we have identified several conditions: the final version of the regression polynomial should have a determination coefficient not less than 0.50 ; the value of the F-criterion not less than 3.0; the number of free members included in the polynomial should be as low as possible.

\section{Results}

As a result of modeling teleroentgenographic characteristics of the soft tissue face profile in young men and women with orthognathic bite, depending on the metric characteristics of the skull, we have constructed linear equations for the following indices (fig. 1, 2):

- A_SS (the thickness of the base of the upper lip or the distance $\left.A^{\prime} \_S s\right)$ - distance from the point $\underline{A}^{\prime}$ to the point $\underline{S s}$;

- COTGSNLS (nasolabial angle) - is formed by lines SnCotg (nasal tangent) and Sn-Ls (labial tangent);

- LI_H_L (distance Li_H line) - distance from the point Li to the line Ls-Pog' ( $\mathrm{H}$ line) (lower lip distance to $\mathrm{H}$-line);

- LI_NSPOG (distance Li_NsPog') - distance from the point Li to the line Ns-Pog' (aesthetic line, is an indicator of the balance of soft tissues, namely the ratio of the lower lip and profile);

- LS_NSPOG (distance Ls_NsPog') - distance from the point Ls to the line Ns-Pog' (aesthetic line, is an indicator of the balance of soft tissues, namely the ratio of the upper lip and the profile);

- LS1U_L (upper lip thickness or distance Ls1u_Ls) distance from the point $\underline{L} \mathbf{s} 1 \mathrm{u}$ to the point $\underline{L}$;

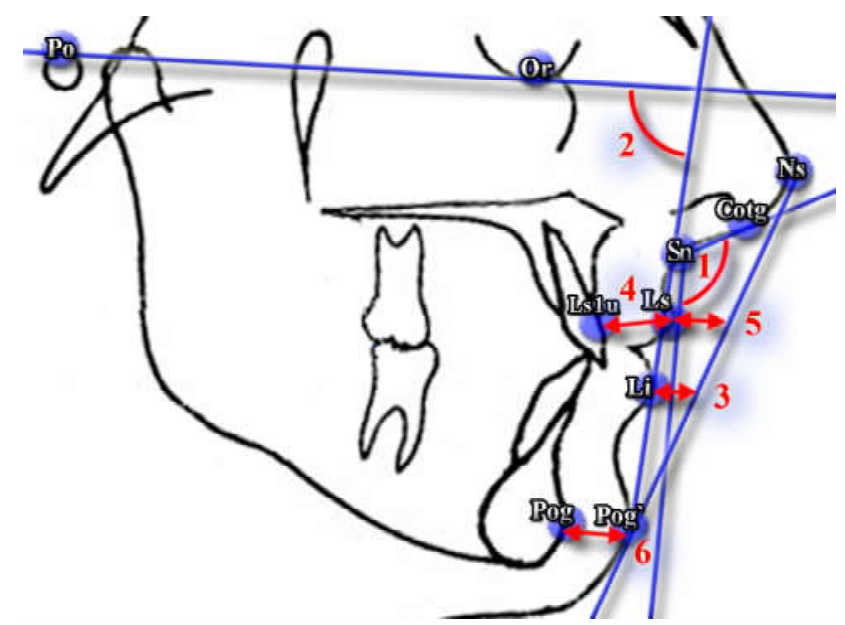

Fig. 1. Teleroentgenographic linear and angular characteristics of the soft facial profile. 1 - nasolabial angle COTGSNLS; 2 - Z angle; 3 - distance Li_NsPog'; 4 - upper lip thickness LS1U_L; 5 - distance Ls_NsPog'; 6 - the thickness of the soft tissues of the chin, distance Pog_Pog'. 


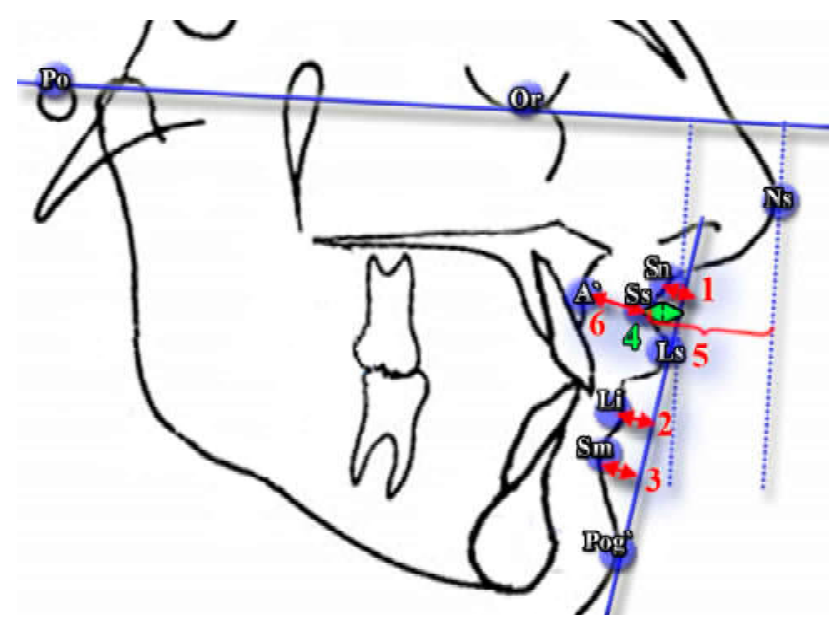

Fig. 2. Teleroentgenographic linear and angular characteristics of the soft facial profile. 1 - distance $\mathrm{Sn}$ _H line; 2 - distance Li_H line; 3 - distance Sm_H line; 4 - the depth of the nasolabial fold, SS_LS; 5 - nose depth, SS_NS; 6 - the thickness of the base of the upper lip or the distance $\overline{A^{\prime}}$ Sss.

- POG_PO (thickness of soft tissue chin or distance Pog_Pog') - distance from the point Pog to the point Pog';

- SM_H_L (distance Sm_H line) - distance from the point $\underline{\mathrm{Sm}}$ to the line $\underline{\mathrm{Ls}-\mathrm{Pog}}$ ( $\mathrm{H}$-line);

- SN_H_L (distance Sn_H line) - distance from the point Sn to the line Ls-Pog' (H-line);

- SS_LS (the depth of the nasolabial fold) - distance from the point Ss to the perpendicular to Po-Or (Frankfurt horizontal), conducted through the point $\underline{\mathrm{LS}}$;

- SS_NS (nose depth) - distance from the point Ss to the tip of the nose $\mathrm{Ns}$ held parallel to the Frankfurt plane;

- $Z$ ( $Z$ angle) - is formed by lines $\underline{\mathrm{Li}-\mathrm{Pog}^{\prime} \text { and Po-Or }}$ (Frankfurt plane, Fp) (the angle between the soft tissue profile, which is defined by the chin lowerlip line and the Frankfurt plane).

Regression models for young men with orthognathic bite have the form of the following linear equations:

A_SS $=19.76+1.005 \times$ MAX $+0.249 \times$ GL_SNPOG + $0.117 \times$ PFH $-0.377 \times$ N_SE $+0.687 \times$ MAX_MAND $-0.190 \times$ F - $0.237 \times$ COND_GN $-0.163 \times$ ANS_ME $\left(R^{2}=0.769\right.$; $F_{(8.27)}=11.23 ; p<0.001$; Error of estimate $\left.=1.124\right)$;

COTGSNLS $=-6.528+2.158 \times$ GL_SNPOG $-1.250 \times$ N_POG_+ $0.371 \times$ GL_SN_S $-3.262 \times$ ANB $+0.782 \times$ MM $\left(R^{2}=0.714 ; F_{(5.30)}=15.00 ; p<0.001 ;\right.$ Error of estimate=6.787);

LI_NSPOG $=32.85+0.384 \times$ N_POG_ $+0.212 \times$ FMA $0.535 \times$ SNA + $0.201 \times$ S_L $-0.237 \times$ MAX_MAND - $0.083 \times$ N_SP_SP $\left(R^{2}=0.789 ; \bar{F}_{(6.29)}=18.03 ; p<0.001\right.$; Error of estimate=1.169);

LS_NSPOG $=-12.20+0.550 \times$ N_POG_- $0.078 \times R \_A S C$ $+0.095 \times$ S_E $-0.068 \times$ GL_SN_S $-0.275 \times A$ A_N_PO +0.072 $x$ NSBA $\left(\mathrm{R}^{2}=0.856 ; \mathrm{F}_{(6.29)}=28.64 ; \mathrm{p}<0 . \overline{0} 0 \overline{1}\right.$; Error of estimate $=0.969)$;

LS1U_L $=3.863+0.607 \times$ MAX $-0.229 \times$ COND_A + $0.137 \times$ GL_SNPOG $-0.296 \times$ A_N_PO $\left(R^{2}=0 . \overline{8} 20\right.$; $F_{(4.31)}=35.29 ; p<0.001$; Error of estimate $=0.710$ );

POG_PO $=-26.30-0.305 \times$ N_POG_ $+0.337 \times$ MAX +
$0.114 \times \mathrm{NSBA}+0.150 \times \mathrm{F}\left(\mathrm{R}^{2}=0.777 ; \mathrm{F}_{(4.31)}=26.96 ; \mathrm{p}<0.001\right.$; Error of estimate $=1.127)$;

SM_H_L $=4.899+0.642 \times$ MAX $-0.227 \times$ COND_A $0.216 \times$ N_POG_- $0.160 \times$ AB_NPOG $-0.105 \times$ ANS_ME $\left(R^{2}=0.638 ; F_{(5.30)}=10.58 ; p<0.001 ;\right.$ Error of estimate=1.091);

SN_H_L $=1.465+0.806 \times$ N_POG_- $0.442 \times$ GL_SNPOG $+0.121 \times \bar{A} F H-0.151 \times P \_O R \_N+0.150 \times S \_E\left(R^{2}=0.930\right.$; $F_{(5.30)}=80.29 ; p<0.001$; Error of estimate $\left.=0.781\right)$;

SS_LS $=0.223-0.265 \times$ GL_SNPOG $+0.335 \times$ N_POG_ $-0.018 \times$ LPALAT $+0.104 \times$ R_ASC $-0.049 \times$ AFH_PFH $\left(R^{2}=0.808 ; F_{(5.30)}=25.21 ; p<0.001\right.$; Error of estimate=0.529);

SS_NS $=-8.455+0.153 \times$ AFH $-0.232 \times$ PN_POG + $0.215 \times \mathrm{PFH}+0.054 \times \mathrm{GL}$ SN_S $\left(\mathrm{R}^{2}=0.723 ; \mathrm{F}_{(4.31)}=20.20\right.$; $\mathrm{p}<0.001$; Error of estimate $=1.573$ );

$Z=-78.71+1.743 \times P \_O R \_N-1.086 \times$ N_POG_- 0.502 x B $-0.168 \times$ S_L $+0.58 \overline{4} \times$ POR_GNS $\left(R^{2}=0.911\right.$; $F_{(5.30)}=61.76 ; p<0.001$; Error of estimate $\left.=2.930\right)$.

Regression models for young women with orthognathic bite have the form of the following linear equations:

A_SS $=-45.54+0.087 \times$ COND_GN $-0.733 \times$ PN_A + $0.258 \times$ N_POG_+ $0.527 \times P \_O R \_N+0.130 \times G L \_S N P O G$ - $0.170 \times$ S_E $\left(R^{2}=0.552 ; \bar{F}_{(6.47)}=9.66 ; p<0.001\right.$; Error of estimate $=1 . \overline{301})$;

COTGSNLS $=92.55+1.925 \times$ GL_SNPOG $-2.385 \times$ N_POG_- $0.502 \times$ N_SP_SP $+2.612 \times \mathrm{F}-1.828 \times$ SNA $0.640 \times$ SN_GOGN + $0.910 \times \mathrm{T}\left(\mathrm{R}^{2}=0.772 ; \mathrm{F}_{(7.43)}=20.82\right.$; $\mathrm{p}<0.001$; Error of estimate $=5.432)$;

LI_H_L $=-2.598+0.245 \times \mathrm{ML} \_\mathrm{NL}+0.213 \times \mathrm{N} \_P O \mathrm{C}_{-}+$ $0.516 \times \overline{A B} \_$NPOG $-0.139 \times \mathrm{FMA}+0.216 \times \mathrm{WITS}+0.44 \overline{9} \times$ ANB $\quad\left(R^{2}=0.610 ; \quad F_{(6.44)}=11.49 ; \quad p<0.001 ;\right.$ Error of estimate=1.016);

LI_NSPOG $=35.88+0.483 \times$ N_POG_ $+0.908 \times$ AB_NPOG $+1.208 \times$ ANB $+0.162 \times \overline{M L} \_\overline{N L}-0.335 \times$ POR_GNS - $0.299 \times$ P_OR_N $\left(R^{2}=0.831 ; F_{(6.44)}=36.08\right.$; $\mathrm{p}<0.001$; Error of estimate $=1.214)$;

LS_NSPOG $=48.58+0.610 \times$ N_POG_ $0.204 \times$ MAX $0.439 \times$ P_OR_N + $0.265 \times$ PN_A - $0.161 \times$ GL_SNPOG $0.179 \times$ POR_GNS $\left(R^{2}=0.858 ; \bar{F}_{(6.44)}=44.44 ; p<0.001\right.$; Error of estimate $=1.046)$;

LS1U_L $=-39.60+0.256 \times$ MAND $+0.119 \times G+0.181 \times$ N_POG_- $0.339 \times P N \_A+0.215 \times$ P_OR_N $-0.155 \times$ ML_NL $\left(R_{2}=0.5 \overline{4} 1 ; F_{(6.44)}=8.63 ; p<0.001 ;\right.$ Error of estimate=1.192);

POG_PO $=96.32-1.020 \times \mathrm{T}+0.558 \times$ NAPOG $-0.855 \times$ $\mathrm{F}+0.387 \times \mathrm{GL}$ SNPOG $-0.122 \times \mathrm{I}+0.077 \times \mathrm{R} \_\mathrm{ASC}$ $\left(R^{2}=0.705 ; F_{(6.44)}=17.53 ; p<0.001 ;\right.$ Error of estimate=1.212);

SM_H_L $=-0.642+0.277 \times$ N_SE - $0.654 \times$ ANS_ME + $0.484 \times \mathrm{AFH}+0.310 \times \mathrm{MM}-0.274 \times \mathrm{T}-0.216 \times \mathrm{I}-0.101 \times$ NBA_PTGN $\left(R^{2}=0.816 ; F_{(7.43)}=27.31 ; p<0.001\right.$; Error of estimate $=0.808)$;

SN_H_L $=-5.832+0.791 \times$ N_POG_ $-0.432 \times$ GL_SNPOG $-0.117 \times$ NBA_PTGN + $0.125 \times$ MAND +0.097 $x$ ML_NSL + $0.044 \times$ N_SP_SP $\left(R^{2}=0.846 ; F_{(6.44)}=40.23\right.$; $\mathrm{p}<0.001$; Error of estimate $=1.096)$;

SS_LS $=-8.183+0.077 \times$ COND_GN $+0.112 \times$ NBA_PTGN + 0.225 xN_POG_- $0.134 \times$ GL_SNPOG -0.112 $x$ SNA $\left(R^{2}=0.590 ; \bar{F}_{(5.45)}=12.94 ; p<0.001\right.$; Error of 
estimate $=0.723$;

SS_NS $=-6,884+0,394 \times \mathrm{AFH}+0,125 \times \mathrm{GL}$ SN_S $0,240 \times \mathrm{H}-0,180 \times \mathrm{N}$-POG_+ 0,252 $\times$ LPALAT $\left(\mathrm{R}^{2}=0, \overline{6} 28\right.$; $F_{(5,45)}=15,20 ; p<0,001 ;$ Error of estimate=1,889);

$\mathbf{Z}=27.93-1.429 \times$ N_POG_+ $0.817 \times \mathrm{P} \_$OR_N -0.309 x ML_NL - $0.549 \times$ AB_NPOG $-0.314 \times \mathrm{T}\left(\bar{R}^{2}=0.927\right.$; $F_{(5.45)}=114.5 ; p<0.001$; Error of estimate=2.660).

In these models: $\mathbf{R}^{2}$ - coefficient of determination; $\mathbf{F}_{(!, ! !)}=! !, ! !$ - critical (!,!!) and got (!!,!!) value of Fisher's criterion; St. Error of estimate - standard error of the standardized regression coefficient; A_N_Po (distance A_N_Pog) distance from the point $A$ to the line N-Pog (the face plane, characterizes the degree of convexity of the face); $A$ B_NPOG - angle formed by lines $\underline{A}-B$ and $N$-Pog, (defines the position of the plane $A B$ in relation to the $\mathrm{N}-\mathrm{Pog}$ ); $\mathrm{AFH}$ (distance $\mathrm{AFH}$ or front height of the face) - distance from the point Me to the line ANS-PNS; AFH_PFH (ratio AFH_PFH) - distance ratio from the point Me to the line ANS-PNS and from the point $\mathrm{Ar}$ to the point $t G o$ (the ratio between the front $(A F H)$ and rear (PFH) face height); ANB (angle ANB) - is formed by lines A-N and N-B (indicates an angular interstitial relation in the anterior-posterior direction; angle ANB is considered positive if point $A$ is in front of NB; if the lines NA and NB overlap, then the ANB angle is $0^{\circ}$; if point $A$ is behind the NB line, then the angle is considered negative); ANS_ME (lower face height) - distance from the point ANS to the point Me; $\mathbf{B}$ (basal angle) - formed by lines ANS-PNS (palatine plane SpP) and Im-Me (mandibular plane MPS by Schwarz) (indicates the angle between the upper and lower jaws); COND_A(effective length of the upper jaw) - distance from the point Cond to the point A; COND_GN (effective length of mandible, or distance

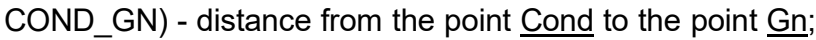
F (face angle or angle F) - formed by lines Se-N and N-A (determines the location of the anterior contour of the upper jaw in the jet plane to the base of the skull); FMA (POr_MeGo) (angle FMA, Frankfort Mandibular Angle) - formed by lines tGo-Me (mandibular plane Mp) та Po-Or (Frankfurt plane $\mathrm{Fp}$ ); $\mathbf{G}$ (angle $\mathrm{G}$, gonial angle, mandibular angle) - is formed by lines ppCond-MT2 and T2-Me, which intersect at the point tGoS; GL_SN_S (index Gl'_Sn_Sn_Gn' or facial vertical index) - distance ratio Gl'-Sn та Sn-Gn' (defines vertical relationships in the face profile); GL_SNPOG (angle GI'SnPog' or indicator of convexity of the soft tissue profile) - formed by lines Gl'-Sn and Sn-Pog'; H (H-angle) - formed by lines Po-Or (Frankfurt plane (Fp) and $\mathrm{Pn}$ (nasal perpendicular, perpendicular to the line from the point $N$ ' to the line Se-N), (defines the angle of the inclination of the Frankfurt plane to the base of the skull); I (inclination angle, angle I) - angle formed by line ANS-PNS and Pn (nasal perpendicular, perpendicular to the line from the point $N$ ' to the line Se-N), (angle of inclination of the upper jaw (spinal plane) to the nasal perpendicular); LPALAT - distance between the point $\underline{\text { ANS }}$ and PNS; MAND (length of the lower jaw) - distance from the constructive point tGoS to the constructive point apMandS; MAX (length of the upper jaw) - distance from the constructive point apMax to the point PNS; MAX_MAND (maxillo-mandibular difference) - difference between distances Cond-A and CondGn; ML_NL (SpP_GoMe, base angle) - formed by lines ANSPNS and tGo-Me (the angle between the palatal SpP and the mandibular MP planes); ML_NSL (angle ML_NSL, or angle SN_GoMe) - formed by lines tGo-Me and $\underline{\mathrm{S}-\mathrm{N}}$, (angle of the mandibular plane inclination to the base of the skull); MM (maxillo-mandibular angle) - is formed by lines A-B and ANS-PNS (defines the angle below which the upper jaw is located in relation to the lower jaw in the jet plane); N_POG_ (angle N'Hold_Pog'_Hline) - angle between lines Ls-Pog' (H line, Holdway line) and N'Hold-Pog'; N_SE (distance Se_N or the length of the front of the skull base by Steiner) - distance from the point Se to the point N; N_SP_SP (coefficient N_Sp'_Sp'_Me) - distance ratio N-Sp' and Sp'-Me (the ratio of the upper and lower height of the face); NAPOG (angle of the skeletal face obliquity, or angle NaPog) - formed by lines $\mathrm{N}-\mathrm{A}$ and A-Pog; NBA_PTGN (angle NBa-PtGn or the angle of the front axle) - formed by lines $\mathrm{N}-\mathrm{Ba}$ and $\mathrm{Pt}-\mathrm{Gn}$ (determines the direction of development of the mandible); NSBA (angle NSBA) - formed by lines S-N (the front part of the skull base) and S-Ba; P_OR_N (soft tissue angle, or angle P_Or_N'Hold_Pog') - formed by lines Po-Or and N'HoldPog'; PFH (distance PFH or rear face height) - distance from the point Ar to the point tGo; PN_A (distance PN_A) - distance from the point $A$ to the point $P N m$ (perpendicular line from the point $N$ to the line Po-Or). If the point $A$ is distal from the nasal perpendicular, then the indicator takes a negative value, and if the medial than a positive value; PN_POG (distance PN_Pog) - distance from the point Pog to the nose perpendicular $\mathrm{PN}$ (perpendicular line from the point $\mathrm{N}$ to the line Po-Or); POR_GNS (Y-axis or angle POr_GnS) - angle formed by lines Po-Or and S-Gn (angle of inclination $\mathrm{Y}$-axis relative to the Frankfurt horizontal); $\mathbf{R}$ ASC (length of the branch of the mandible) - distance from constructive points $\underline{\text { R.asc }}$ to a constructive point tGoS; S_E (- distance S_E or the length of the back of the skull base by Steiner) - distance from the point $S$ to a constructive point $E$, which is located at an intersection of the perpendicular carried out from the point ppCond to the line S-N; S_L (distance $S_{-} \mathbf{L}$ or the front length of the skull base by Steiner) - from the point $S$ to a constructive point $L$, which is formed at the intersection of the perpendicular carried out from the point Pog to the line Se-N; SN GOGN (angle SN_GoGn) - formed by lines Go-Gn and S-N (angle of inclination (MpSt) mandibular plane by Steiner, to the base of the skull); SNA (angle SNA) - formed by lines S-N and $\underline{\mathrm{N}-}$ $\underline{A}$, (the angle indicates the anterior-posterior position of the upper jaw to the base of the skull); $\mathbf{T}$ (profile angle T) - formed

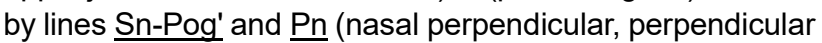
to the line from the point $\underline{N^{\prime}}$ to the line Se-N); WITS (indicator Wits) - distance between constructive points AOcIP and BOcIP - projections of the corresponding points $A$ and $B$ on the line apOcP-ppOcP (OcPSt, closing plane by Steiner) (indicates a linear interjaw ratio in the anterior-posterior direction; if the projection of point $A$ lies ahead of the projection of point $B$ then the indicator takes a positive value; if the projection of point $A$ lies behind the projection of point $B$ then the indicator 
takes a negative value).

Models of the following individual teleroentgenographic characteristics of the of soft tissue face profile in young men and women with orthognathic bite have a determination coefficient of less than 0.5 and therefore irrelevant for practical medicine: GI_Sn_S (Gl'Sn_Sn_Gn' index or facial vertical index) - distance ratio $\underline{\mathrm{G}} \mathrm{I}^{\prime}-\mathrm{Sn}$ and $\mathrm{Sn}-\mathrm{Gn}^{\prime}$ (defines vertical relations in the face profile); GISNPOG (angle GI'SnPog' or index of convexity of the soft tissue profile) - is formed by the lines Gl'-Sn and Sn-Pog'; P_Or_N (soft tissue angle, or angle P_Or_N'Hold_Pog') - is formed by lines Po-Or and N'HoldPog'; $\mathbf{T}$ (profile angle T) - is formed by the lines Sn-Pog' and $\underline{P n}$ (nasal perpendicular, perpendicular to the line from the point N' to the line Se-N); GISNPOG (angle GI'SnPog' or index of convexity of the soft tissue profile) - is formed by the lines Gl'-Sn and Sn-Pog'; N_POG_(angle N'Hold_Pog'_Hline) the angle between the lines Ls-Pog' (H-line, Holdway line) and N'Hold-Pog'.

\section{Discussion}

The level of modern medicine requires the application of not only standard average figures but also requires the identification of individualized diagnostic values. For solving such problems, methods of regression and correlation analysis are increasingly used, which allow to establish not only the existence of various dependencies between different anatomical head structures and dental-maxillary system parameters [5, 22, 23], but also allow more accurately predict the change in the contour of soft facial tissues in response to orthodontic treatment [28].

Reliable models (with a determination coefficient greater than 0.50 ) of individual teleroentgenographic characteristics of the facial soft tissues of the person for the determination of the orthodontic diagnosis, planning and control of dental anomalies treatment were developed using the method of step-by-step regression with inclusion, for the Ukrainians of adolescence age, based on the specifics of teleroentgenographic indices. It was established that in young men from 19 possible models, 11 were constructed with determination coefficient $R^{2}$ from 0.638 to 0.930 , and in young women - 12 models with determination coefficient R2 from 0.541 to 0.927 .

The analysis of models showed that in young men with orthognathic bite most often the regression equations

\section{References}

[1] Al Taki, A., Yaqoub, S., \& Hassan, M. (2018). Legan-burstone soft tissue profile values in a Circassian adult sample. Journal of orthodontic science, 7, 18. doi: 10.4103/jos.JOS_27_18

[2]Al-Barakati, S. F. (2011). Soft tissue facial profile of adult Saudis. Saudi Med. J., 32(8), 836-842. PMID: 21858394

[3] Alley, T. R., \& Hildebrandt, K. A. (1998). Determinants and consequences of facial esthetics: social and applied aspects of perceiving faces. $\mathrm{NJ}$ : Lawrence Erlbaum Associates.

[4] Anić-Milosević, S., Lapter-Varga, M., \& Slaj, M. (2008). Analysis of the soft tissue facial profile by means of angular measurements. Eur. J. Orthod., 30(2), 135-140. doi: 10.1093/ included - the angle N_POG, parameters of which indicate a linear interjaw relation in the anterior-posterior direction (14.0\%); angle GL_SNPOG, or index of convexity of the soft tissue profile (8.8\%); MAX upper jaw length (7.0\%), and GL_SN_S index, which defines vertical correlations in the face profile $(5.3 \%)$. In young women with orthognathic bite most often the models included - angle N_POG (12.5\%); angle GL_SNPOG (7.5\%); soft tissue facial angle P_OR_N (6.25\%); the basis angle ML_NL and the profile angle T (by $5.0 \%$ ); the angle AB_NPOG, the angle NBA_PTGN, which defines the direction of development of the mandible and the distance PN_A (by 3.75\%).

In a previous study [12] when modeling individual angular positions of teeth in young men with orthognathic bite of 40 possible regression models of CT indices characterizing the position of individual teeth relative to each other, to the bone cranial structures and profile of the face, 23 with a determination coefficient from 0.557 to 0.832 were constructed, which most often (from 3.9 to $7.0 \%$ ) included WITS indicator, GL_SNPOG angle, distance S_E, angle MM, angle NSBA, angle AB_NPOG, angle N_POG_, distance N_SE, coefficient N_SP_SP and angle P_OR_N. In young women only 8 models with a determination coefficient of 0.581 to 0.832 were constructed, which most often (6.1 to $14.3 \%$ ) included the angle N_POG_, the angle AB_NPOG, the WITS indicator, the angle of the MM, the angle ANB and the length of the lower jaw branch R_ASC.

The models we have developed will help dentists to achieve in the orthodontic treatment of maximum physiological and aesthetic results.

\section{Conclusions}

In young men with normal occlusion close to the orthognathic bite of 19 possible models, 11 were constructed with a determination coefficient from 0.638 to 0.930 , and in young women -12 models with a determination coefficient from 0.541 to 0.927 . In young men, the most commonly included models were N_POG angle (14.0\%), angle GL_SNPOG (8.8\%), MAX maximal jaw $(7.0 \%)$ and index GL_SN_S (5.3\%); and in young women - the angle of N_POG (12.5\%); angle GL_SNPOG (7.5\%); soft tissue facial angle P_OR_N (6.25\%); the base angle $\mathrm{ML}$ NL and the profile angle $\mathrm{T}$ (by $5.0 \%$ ); the angle $\mathrm{AB}$ NPOG, the angle NBA_PTGN and the distance PN_A (by $3.75 \%$ ).

ejo/cjm116

[5] Bingmer, M., Ozcan, V., Jo, J. M., Lee, K. J., Baik, H. S., \& Sneider, G. (2010). A new concept for the cephalometric evaluation of craniofacial pattern (multiharmony). Eur. J. Orthod., 32(6), 645-654. doi: 10.1093/ejo/cjp152

[6] Celebi, A. A., Tan, E., Gelgor, I. E., Colak, T. \& Ayyildiz, E. (2013). Comparison of Soft Tissue Cephalometric Norms between Turkish and European-American Adults. The Scientific World Journal, 2013, 806203 doi: 10.1155/2013/806203

[7] Dmitriev, M. O. (2016). Definition of normative cephalometric parameters by Steiner method for Ukrainian young men and 
women. World of Medicine and Biology, 3(57), 28-32.

[8] Dmitriev, M. O. (2017). Identification of normative cephalometric parameters based on $\mathrm{G}$. Schmuth method for young male and female Ukrainians. Reports of Morphology, 23(2), 288-292.

[9] Dmitriev, M. O. (2018). Determination of standard cephalometric parameters using the Downs method for Ukrainian adolescents. Reports of Morphology, 24(2), 22-26. doi: 10.31393/morphology-journal-2018-24(2)-03

[10] Dmitriev, M. O., Chugu, T. V., Gerasymchuk, V. V., \& Cherkasova, O. V. (2017). Determination of craniometric and gnatometric indicators by A. M. Schvartz metod for Ukrainian boys and girls. Biomedical and Biosocial Anthropology, 29, 53-58.

[11] Dmitriev, M. O., Tikholaz, V. O., Shepitko, K. V., ShinkarukDykovytska, M. M., Androshchuk, O. V., Bobruk, S. V., \& Zakalata, T. R. (2018). Sexual dimorphism of normative cephalometric parameters determined by the Holdaway method in boys and girls of Podillia. World of Medicine and Biology, 2(64), 39-43. doi: 10.26724/2079-8334-2018-2-64-39-43

[12] Dmitriev, M. O., Volkov, K. S., Glushak, A. A., Kyrychenko, Yu. V., Balynska M. V., Chugu, T. V., Kovalchuk O. I. (2018). Determination of individual angular characteristics of the teeth positions according to the computer tomography in Ukrainian adolescents with orthognathic bite. Biomedical and Biosocial Anthropology, 31, 44-52. doi: 10.31393/bba31-2018-06

[13] Garg, R., \&Alexander, M. (2015). "Are we similar to caucasians": Orthognathic surgery for north Indians. J. Maxillofac. Oral Surg., 14(2), 271-277. doi: 10.1007/s12663-014-0636-6

[14] Gonzalez, M. B., Caruso, J. M., Sugiyama, R. M., \& Schlenker, W. L. (2013). Establishing cephalometric norms for a Mexican population using Ricketts, Steiner, Tweed and Arnett analyses. APOS Trends in Orthodontics, 3(6), 171-177. doi: 10.4103/ 2321-1407.121437

[15] Gunas, I. V., Dmitriev, M. O., Tikholaz, V. O., ShinkarukDykovytska, M. M., Pastukhova, V. A., Melnik, M. P., \& Rudiy, Yu. I. (2018). Determination of normal cephalometric parameters by J. McNamara method for Ukrainian boys and girls. World of Medicine and Biology, 1(63), 19-22. doi: 10.26724/2079-8334-2018-1-63-19-22

[16] Gunas, I. V., Dmitriev, M. O., Prokopenko, S. V., ShinkarukDykovytska, M. M., \& Yeroshenko, G. A. (2017). Determination regulatory cephalometric options by the method of Tweed International Foundation for Ukrainian boys and girls. World of Medicine and Biology, 4(62), 27-31. doi: 10.26724/2079-83342017-4-62-27-31

[17] Jabbara, A., Ziab, A. U., Shaikh, I. A., Channard, K. A., \& Bari, A. (2016). Evaluation of soft tissue chin thickness in various skeletal malocclusions. Pakistan Orthodontic Journal, 8(1), 62-66.

[18] Joshi, M., Wu, L. P., Maharjan, S., \& Regmi, M. R. (2015). Sagittal lip positions in different skeletal malocclusions: a cephalometric analysis. Prog. Orthod., 16, 8. doi: 10.1186/ s40510-015-0077-x

[19] Marchiori, G. E., Sodre, L. O., da Cunha, T. C., Torres, F. C., Rosario, H. D., \& Paranhos, L. R. (2015). Pleasantness of facial profile and its correlation with soft tissue cephalometric parameters: Perception of orthodontists and lay people. Eur. J. Dent., 9(3), 352-355. doi: 10.4103/1305-7456.163323

[20] Oliveira, M. T., \& Candemil, A. (2013). Assessiment of the correlation between cephalometric and facial analysis. J. Res. Dent., 1(1), 34-40. doi: http://dx.doi.org/10.19177/ jrd.v1e1201334-40

[21] Oz, A. Z., Akcan, C. A., El, H., \& Ciger, S. (2014). Evaluation of the soft tissue treatment simulation module of a computerized cephalometric program. Eur. J. Dent., 8(2), 229-233. doi: 10.4103/1305-7456.130614

[22] Perinetti, G., Ceschi, M., Scalia, A., \& Contardo, L. (2018). Cephalometric Floating Norms for the B Angle and MMBPWits. Hindawi BioMed Research International, Article ID 8740731. doi: https://doi.org/10.1155/2018/8740731

[23] Perinetti, G., Cordella, C., Pellegrini, F., \& Esposito, P. (2008). The prevalence of malocclusal traits and their correlations in mixed dentition children: results from the Italian OHSAR Survey. Oral Health \& Preventive Dentistry, 6(2), 119-129. PMID: 18637389

[24] Perović, T., \& Bla?ej, Z. (2018). Male and Female Characteristics of Facial Soft Tissue Thickness in Different Orthodontic Malocclusions Evaluated by Cephalometric Radiography. Med. Sci. Monit., 24, 3415-3424. doi: 10.12659/MSM.907485

[25] Prasad, M., Chaitanya, N., Reddy, K. P., Talapaneni, A. K., Myla, V. B., \& Shetty, S. K. (2014). Evaluation of nasal morphology in predicting vertical and sagittal maxillary skeletal discrepancies. Eur. J. Dent., 8(2), 197-204. doi: 10.4103/1305-7456.130600

[26] Profit, R. W., Fields, H. W., \& Sarver, D. M. (trans. from the English; Ed. L.S. Persina) (2006). Modern Orthodontics. M.: MEDpress-inform. ISBN 978-5-00030-448-8

[27] Sforza, C., Laino, A., D'Alessio, R., Grandi, G., Tartaglia, G. M., \& Ferrario, V. F. (2008). Soft-tissue facial characteristics of attractive and normal adolescent boys and girls. Angle Orthod., 78(5), 799-807. doi: 10.2319/091207-431.1

[28] Shirvani, A., Sadeghian, S., \& Abbasi, S. (2016). Prediction of lip response to orthodontic treatment using a multivariable regression model. Dent. Res. J. (Isfahan), 13(1), 38-45. doi: 10.4103/1735-3327.174697

[29] Somaiah, S., Khan, M. U., Muddaiah, S., Shetty, B., Reddy, G., \& Siddegowda, R. (2017). Comparison of soft tissue chin thickness in adult patients with various mandibular divergence patterns in Kodava population. Int. J. Orthod. Rehabil., 8(2), 51-56. doi: 10.4103/ijor.ijor_38_16

[30] Taki, A. A., Oguz, F., \& Abuhijleh, E. (2009). Facial soft tissue values in persian adults with normal occlusion and wellbalanced faces. Angle Orthod., 79(3), 491-454. doi: 10.2319/ 020408-62.1

\section{ВИЗНАЧЕННЯ ІНДИВІДУАЛЬНИХ ТЕЛЕРЕНТГЕНОГРАФІЧНИХ ХАРАКТЕРИСТИК ПРОФІЛЮ М'ЯКИХ ТКАНИН ОБЛИЧЧЯ У УКРАЇНСЬКИХ ЮНАКІВ І ДІВЧАТ ІЗ ОРТОГНАТИЧНИМ ПРИКУСОМ \\ Дмітрієе М. 0 .}

Сучасна стоматологія вимагає визначення індивідуалізованих значень телерентгенографічних показників. Для вирішення подібних завдань все частіше використовують методи регресійного та кореляційного аналізів, які допомагають встановити не лише наявність різного роду залежностей між анатомічними структурами голови та параметрами зубощелепної системи, але і дозволяють більш точно передбачати зміні контуру м'яких тканин обличчя у відповідь на ортодонтичне лікування. Мета дослідження - шляхом вивчення цефралометричних показників юнаків і дівчат України із нормальною оклюзією та збалансованими обличчями і проведення прямого покрокового регресійного аналізу розробити математичні моделі визначення індивідуальних телерентгенографічних характеристик профрілю м'яких тканин обличчя. За допомогою пристрою Veraviewepocs 3D, Моріта (Япония) у 38 юнаків (віком від 17 до 21 року) та 55 дівчат (віком від 16 до 20 років) з оклюзією, 
наближеною до ортогнатичного прикусу та збалансованими обличчями були отримані бокові телерентгенограми.

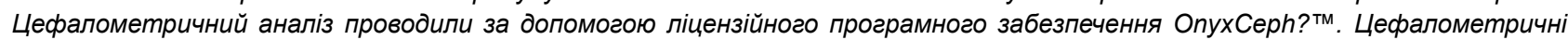
точки та вимірювання проводили згідно рекомендацій Downs W. B., Holdway R. A., McNamara J., Schwarz A. M., Schmuth G. P. F., Steiner C. C. ma Tweed C. H. За допомогою прямого покрокового регресійного аналізу, в ліцензійному пакеті "Statistica 6.0", будували регресійні моделі індивідуальних телерентгенографрічних характеристик профрілю м'яких тканин обличчя. В юнаків із нормальною оклюзією, наближеною до ортогнатичного прикусу із 19 можливих моделей побудовано 11 з коефріцієнтом детермінації від 0,638 до 0,930, а у дівчат - 12 моделей з коефіцієнтом детермінації від 0,541 до 0,927. Проведений аналіз моделей показав, що в юнаків найбільш часто до регресійних рівнянь входили - кут N_POG, параметри якого вказують на лінійне міжщелепне співвідношення у передньо-задньому напрямку (14,0\%); куm $\overline{G L} S N P O G$, або показник опуклості м'якотканинного профрілю (8,8\%); довжина верхньої щелепи MAX (7,0\%), а також індекс GL_SN_S, який визначає вертикальні співвідношення у лицевому профрілі (5,3\%). У дівчат найбільш часто до моделей входили - кут N_POG $(12,5 \%) ;$ куm GL_SNPOG (7,5\%); м'якотканний лицевий кут P_OR_N (6,25\%); базисний кут ML_NL та профрільний кут T (по 5,0\%); кут AB_NPOG, куm NBA_PTGN, який визначає напрямок розвитку нижньої щелепи та відстань PN_A (по 3,75\%). Таким чином, в роботі, за допомогою методу покрокової регресії з включенням, у українців юнацького віку, на основі особливостей телерентгенографрічних показників розроблені та проаналізовані достовірні моделі індивідуальних телерентгенографрічних характеристик профрілю м'яких тканин обличчя.

Ключові слова: профріль обличча, телерентгенографрія, регресійний аналіз.

\section{ОПРЕДЕЛЕНИЕ ИНДИВИДУАЛЬНЫХ ТЕЛЕРЕНТГЕНОГРАФИЧЕСКИХ ХАРАКТЕРИСТИК ПРОФИЛЯ МЯГКИХ ТКАНЕЙ ЛИЦАУ УКРАИНСКИХ ЮНОШЕЙ И ДЕВУШЕК С ОРТОГНАТИЧЕСКИМ ПРИКУСОМ \\ Дмитриев Н. A.}

Современная стоматология требует определения индивидуализированных значений телерентгенографических показателей. Для решения подобных задач все чаще используют методы регрессионного и корреляционного анализов, которые помогают установить не только наличие различного рода зависимостей между анатомическими структурами головы и параметрами зубочелюстной системы, но и позволяют более точно предсказывать изменения контура мягких тканей лица в ответ на ортодонтическое лечение. Цель исследования - путем изучения цефалометрических показателей юношей и девушек Украины с нормальной окклюзией и сбалансированными лицами и проведения прямого пошагового регрессионного анализа разработать математические модели определения индивидуальных телерентгенографических характеристик профиля мягких тканей лица. С помощью устройства Veraviewepocs 3D, Морита (Япония) у 38 юношей (в возрасте от 17 до 21 года) и 55 девочек (в возрасте от 16 до 20 лет) с окклюзией, приближенной к ортогнатическому прикусу и сбалансированными лицами были получены боковые телерентгенограммы. Цефалометрический анализ проводили

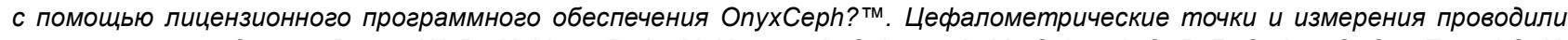
согласно рекомендациям Downs W. B., Holdway R. A., McNamara J., Schwarz A. M., Schmuth G. P. F., Steiner C. C. u Tweed C. H. C помощью прямого пошагового регрессионного анализа, в лицензионном пакете "Statistica 60", построены регрессионные модели индивидуальных телерентгенограффических характеристик профиля мягких тканей лица. У юношей с нормальной окклюзией приближенной к ортогнатическому прикусу из 19 возможных моделей построено 11 с коэффрициентом детерминации от 0,638 до 0,930, а у девушек - 12 моделей с коэфффициентом детерминации от 0,541 до 0,927. Проведенный анализ моделей показал, что у юношей наиболее часто к регрессионным уравнениям входили - угол N_POG, параметры которого указывают на линейное межчелюстное соотношение в передне-заднем направлении (14,0\%); угол GL_SNPOG, или показатель выпуклости мягкотканного профиля (8,8\%); длина верхней челюсти MAX (7,0\%), а также uндекс $\bar{G} L \_S N \_S$, который определяет вертикальные соотношения в лицевом профиле (5,3\%). У девушек наиболее часто в модели входили - угол N_POG (12,5\%); угол GL_SNPOG (7,5\%); мягкотканный лицевой угол P_OR_N (6,25\%); базисный угол ML_NL u профильный угол $T$ (по 5,0\%); угол AB_NPOG, угол NBA_PTGN, который определяет направление развития нижней челюсти и расстояние PN_A (по 3,75\%). Таким образом, в работе, с помощью метода пошаговой регрессии с включением, у украинцев юношеского возраста, на основе особенностей телерентгенографических показателей разработаны и проанализированы достоверные модели индивидуальных телерентгенографических характеристик профриля мягких тканей лица. Ключевые слова: профиль лица, телерентгенография, регрессионный анализ. 